\title{
The effect of cultivar type, time of cultivation, and biostimulant treatment on the yield of spinach (Spinacia oleracea L.)
}

\author{
Edward Kunicki', Aneta Grabowska', \\ Agnieszka Sękara ${ }^{1}$, Renata Wojciechowska ${ }^{2}$ \\ ${ }^{1}$ Department of Vegetable Crops and Horticultural Economics \\ ${ }^{2}$ Department of Botany and Plant Physiology \\ Agricultural University in Krakow \\ 29-Listopada 54, 31-425 Kraków, Poland \\ e-mail: e.kunicki@ur.krakow.pl
}

\begin{abstract}
The aim of the present study was to investigate the influence of spraying with Aminoplant on the yield of two spinach cultivars in the spring and autumn cultivations. The experiment was carried out in 2008 and 2009 in the experimental station of the University of Agriculture in Krakow, Poland. Three factors were taken into consideration: (1) cultivar: 'Rembrandt $\mathrm{F}_{1}$ ' and 'Spiros $\mathrm{F}_{1}$ '; (2) time of cultivation: spring and autumn; (3) dose of Aminoplant: control (without Aminoplant), $1.5 \mathrm{dm}^{3} \mathrm{ha}^{-1}$ and $3.0 \mathrm{dm}^{3} \mathrm{ha}^{-1}$. The spinach yield was dependent on the time of production and cultivar type, and ranged between 18.6-44.8 $\mathrm{t} \mathrm{ha}^{-1}$. Both cultivars yielded better in autumn cultivation. Spraying with Aminoplant had no effect on spinach yield. Dry matter content in spinach

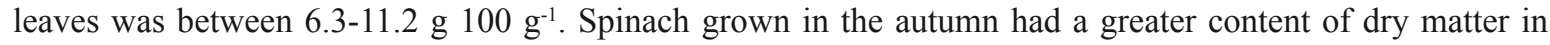
comparison to the spring cultivation. In 2009 , 'Rembrant $\mathrm{F}_{1}$ ' was characterized by greater dry matter content than 'Spiros $\mathrm{F}_{1}$ '. Aminoplant in a dose of $3.0 \mathrm{dm}^{3} \mathrm{ha}^{-1}$ lowered dry matter content in spinach leaves as compared to the control. The nitrate content in spinach was differentiated (558-3506 mg NO $\mathrm{kg}^{-1} \mathrm{f} . \mathrm{m}$.) and depended on the time of cultivation, the cultivar, and the Aminoplant dose.
\end{abstract}

Key words: Aminoplant, biostimulation, nitrates

\section{INTRODUCTION}

Spinach is becoming more popular in Poland, as evidenced by increases in the consumption of both fresh (salads) and processed cultivars. Spinach is a vegetable with a high biological value, extremely rich in antioxidants especially when fresh, steamed, or quickly boiled (Cho et al. 2008). It is a good source of vitamin $\mathrm{A}, \mathrm{C}, \mathrm{E}, \mathrm{K}, \mathrm{B}_{2}, \mathrm{~B}_{6}, \mathrm{~B}_{9}$, folic acid, minerals ( $\mathrm{Mn}, \mathrm{Mg}, \mathrm{Fe}, \mathrm{K}, \mathrm{Ca}, \mathrm{Se}$ ), and dietary fiber. Through diet, it might be possible to counter decreases in antioxidant protection that occur with age by increasing the intake of fruits and vegetables identified as being high in antioxidant activity, such as spinach (Cao et al. 1996). Because of this, modern ecological methods should be supported to improve the quality and quantity of spinach yields.

Biostimulants are biologically active substances that enhance metabolisms and promote plant growth when applied in small quantities. Biostimulants include hormones, enzymes, proteins, amino acids, vitamins, microelements and other compounds. Most biostimulants are synthetic agents, whereas plant and alga extracts are also very popular (Dobromilska et al. 2009, Grabowska and Kunicki 2009). Some of these induce systemic resistance against pathogenic factors or physical injuries (alga 
extracts, betaine), while others supply organic or mineral compounds ready for use by plants, such as titanium or amino acids (Stępowska 2008). Biostimulants can be successfully used in vegetable production to improve plant tolerance to stress factors, plant health, productivity and yielding at different growth stages. It is an environmentally friendly method of improving plant development that reduces fertilizer and pesticide consumption. The results of biostimulant application are dependent on plant species, cultivar type, environmental factors, dose and time of application. Yildirim et al. (2002) found a positive effect of biostimulant on seed germination of some vegetable species under stress conditions. Vernieri et al. (2002) positively evaluated the effects of biostimulants on the growth and quality of lettuce and tomato seedlings during the cultivation period in the nursery. Amanda et al. (2009) suggested that applications of biostimulants might be used for stimulating nutrient use efficiency and improving the quality of baby leaf vegetables. Biostimulants can be soil- or leaf-applied, depending on their composition and expected results. Grabowska and Kunicki (2009) treated broccoli with Aminoplant, a leaf-applied biostimulant, in the transplant stage and soil-applied Goëmar Goteo before head formation with a positive effect on the yield.

Aminoplant (Siapton ${ }^{\circledR}$ ) ISAGRO, Italy, an amino acid based biostimulant, was developed in Italy more than 35 years ago. Its application results in plant growth stimulation due to positive action on some enzyme systems, a strong effect towards abiotic and biotic stress due to the same enzyme systems, as well as a high content of proline and hydroxyproline, positive action on the plant growth regulators, enhancement of flower fertility and fruit setting and the stimulation of nutrient absorption due to chelate and complex formation (Maini 2006). Positive effects of Aminoplant application were found on many vegetables, such as broccoli, potato, tomato, cucurbits, and carrot (Maini 2006, Grabowska and Kunicki 2009) but there is no information about the effect of this biostimulant on spinach. The aim of the present study was to investigate the influence of spraying with Aminoplant on the yield of two spinach cultivars in the spring and autumn cultivations.

\section{MATERIAL AND METHODS}

The experiment was carried out in 2008 and 2009 in the experimental station of the University of Agriculture in Krakow, Poland to investigate the effect of the Aminoplant biostimulant on the yield of spinach (Spinacia oleracea L.). The experiment was established using soil with an organic carbon content of $2 \%$, and $\mathrm{pH}_{\mathrm{KCl}} 6.11$. Based on the chemical soil analysis (Tab. 1), fertilizers were applied in the required levels for the tested species. Seeds were sown in a dose of $30 \mathrm{~g}$ per $10 \mathrm{~m}^{2}$, during the following times: 28 March and 13 August 2008, 23 March and 14 August 2009. The experimental plot area was $3 \mathrm{~m}^{2}$. The experiment was established using the randomized block method in four replications. Three factors were taken into consideration: (1) cultivar: 'Rembrandt $\mathrm{F}_{1}$ ' and 'Spiros $\mathrm{F}_{1}$ '; (2) time of cultivation: spring and autumn; (3) dose of Aminoplant: control (without Aminoplant), $1.5 \mathrm{dm}^{3}$ $\mathrm{ha}^{-1}$ and $3.0 \mathrm{dm}^{3} \mathrm{ha}^{-1}$. The spinach was sprayed with Aminoplant in two phases of its growth: two-leaf and four-leaf plants. The spinach was harvested on 23 May, 2008, 14 October, 2008, 25 May and 1 October, 2009. The reaction of the plants towards the Aminoplant spraying was assessed by the yield quantity and analysis of dry matter and nitrate in the leaves. Dry matter was determined according to the Pijanowski method. Nitrate ion content in the plant material was determined using the ORION 920Aplus ionometer, Thermo Electron Corp. (samples were extracted in $0.02 \mathrm{M} \mathrm{Al}_{2}\left(\mathrm{SO}_{4}\right)_{3}$ $\left.18 \mathrm{H}_{2} \mathrm{O}\right)$. All results were analyzed statistically using the ANOVA method and the Tukey test at $\alpha=0.05$.

\section{RESULTS AND DISCUSSION}

Spinach reaches its edible maturity quickly and thrives best during the cool, moist seasons of the year. During periods of warm weather and long

Table 1. Results of soil analysis in 2008-2009

\begin{tabular}{|c|c|c|c|c|c|c|c|c|c|}
\hline \multirow{2}{*}{ Year } & \multirow{2}{*}{$\begin{array}{l}\text { Time of } \\
\text { cultivation }\end{array}$} & $\mathrm{N}-\mathrm{NH}_{4}$ & $\mathrm{~N}-\mathrm{NO}_{3}$ & $\mathrm{P}$ & $\mathrm{K}$ & $\mathrm{Ca}$ & $\mathrm{Mg}$ & \multirow{2}{*}{$\begin{array}{c}\mathrm{NaCl} \\
\left(\mathrm{g} \mathrm{dm}^{-3}\right)\end{array}$} & \multirow{2}{*}{$\mathrm{pH}$} \\
\hline & & \multicolumn{6}{|c|}{$\left(\mathrm{mg} \mathrm{dm}^{-3}\right)$} & & \\
\hline \multirow[t]{2}{*}{2008} & Spring & 35.0 & 38.5 & 59.0 & 146.6 & 1287 & 113.2 & 0.32 & 7.35 \\
\hline & Autumn & 15.7 & 77.0 & 53.0 & 277.0 & 1767 & 100.7 & 0.48 & 7.64 \\
\hline \multirow[t]{2}{*}{2009} & Spring & 22.7 & 21.0 & 42.5 & 259.7 & 1912 & 80.6 & 0.27 & 7.71 \\
\hline & Autumn & 14.0 & 101.5 & 49.0 & 95.4 & 812 & 101.3 & 0.29 & 7.08 \\
\hline
\end{tabular}


Table 2. Marketable yield of spinach $\left(\mathrm{t} \mathrm{ha}^{-1}\right)$ depending on the time of cultivation, cultivar and biostimulant treatment

\begin{tabular}{|c|c|c|c|c|c|}
\hline \multirow{2}{*}{ Treatment } & \multicolumn{2}{|l|}{ Spring } & \multicolumn{2}{|l|}{ Autumn } & \multirow{2}{*}{ Mean for treatment } \\
\hline & 'Rembrandt $\mathrm{F}_{1}{ }^{\prime}$ & 'Spiros $F_{1}$ ' & 'Rembrandt $\mathrm{F}_{1}{ }^{\prime}$ & 'Spiros $F_{1}$ ' & \\
\hline \multicolumn{6}{|c|}{2008} \\
\hline Control & $18.6 \mathrm{a}^{*}$ & $21.5 \mathrm{a}$ & $36.8 \mathrm{~b}$ & $42.7 \mathrm{c}$ & $29.90 \mathrm{AB}$ \\
\hline Aminoplant $1.5 \mathrm{dm}^{3} \mathrm{ha}^{-1}$ & $20.2 \mathrm{a}$ & $22.6 \mathrm{a}$ & $32.9 \mathrm{~b}$ & $43.1 \mathrm{c}$ & $29.70 \mathrm{~A}$ \\
\hline Aminoplant $3.0 \mathrm{dm}^{3} \mathrm{ha}^{-1}$ & $21.8 \mathrm{a}$ & $22.2 \mathrm{a}$ & $36.1 \mathrm{~b}$ & $44.8 \mathrm{c}$ & $31.23 \mathrm{~B}$ \\
\hline Mean for cultivar & $20.20 \mathrm{~A}^{* *}$ & $22.10 \mathrm{~B}$ & $35.27 \mathrm{C}$ & $43.54 \mathrm{D}$ & \\
\hline Mean for time of cultivation & $21.15 \mathrm{~A}$ & & $39.41 \mathrm{~B}$ & & \\
\hline \multicolumn{6}{|c|}{2009} \\
\hline Control & $24.2 \mathrm{a}$ & $23.1 \mathrm{a}$ & $34.7 \mathrm{bc}$ & $35.0 \mathrm{bc}$ & $29.25 \mathrm{~A}$ \\
\hline Aminoplant $1.5 \mathrm{dm}^{3} \mathrm{ha}^{-1}$ & $24.9 \mathrm{a}$ & $24.3 \mathrm{a}$ & $33.5 \mathrm{bc}$ & $38.9 \mathrm{c}$ & $30.40 \mathrm{AB}$ \\
\hline Aminoplant $3.0 \mathrm{dm}^{3} \mathrm{ha}^{-1}$ & $29.1 \mathrm{ab}$ & $26.4 \mathrm{a}$ & $35.1 \mathrm{bc}$ & $35.9 \mathrm{c}$ & $31.63 \mathrm{~B}$ \\
\hline Mean for cultivar & $26.07 \mathrm{~A}$ & $24.60 \mathrm{~A}$ & $34.44 \mathrm{~B}$ & $36.60 \mathrm{~B}$ & \\
\hline Mean for time of cultivation & $25.34 \mathrm{~A}$ & & $35.52 \mathrm{~B}$ & & \\
\hline
\end{tabular}

*Values for particular years of the experiment marked with the same letter do not differ significantly at $\alpha=0.05$

$* *$ Values for particular objects marked with the same capital letter do not differ significantly at $\alpha=0.05$

days, spinach will form flower stems; therefore, it is cultivated mainly in the spring or autumn in Poland. In the present experiment, the time of production was a leading factor in determining the yield and dry matter content of the spinach. Both the 'Rembrandt $\mathrm{F}_{1}$ ' and 'Spiros $\mathrm{F}_{1}$ ' cultivars had decreased yields during the spring cultivation (Tab. 2). In spring and autumn 2008 and autumn 2009, 'Spiros $\mathrm{F}_{1}$ ' yielded better than 'Rembrandt $\mathrm{F}_{1}$ '. Spraying with Aminoplant in a dose of 3.0 $\mathrm{dm}^{3} \mathrm{ha}^{-1}$ had a significant effect on spinach yield as compared to the control only in 2009. Generally, different crops treated with this biostimulant had increased yields per hectare (Maini 2006). These results could not be explained by fertilizing action due to the organic nitrogen content. The capacity to increase yields in quality and quantity was due to the complexity of the biostimulants, i.e. amino acid quality and ratio, length of peptide chains, different molecular weight ratio of peptides, etc. (Maini 2006). Grabowska and Kunicki (2009) showed that leaf-applied Aminoplant increased the early yield of broccoli in the autumn cultivation by $17 \%$. In greenhouse cultivation, lettuce sprayed with Aminoplant had a higher head mass and increased dry matter content in the leaves (Kowalczyk and Zielony 2008). Łyszkowska et al. (2008) received similar results in field lettuce cultivation. In the present experiment, spinach grown in the autumn had a greater content of dry matter in comparison to the spring cultivation (Tab. 3). The differences between cultivars in dry matter content were significant only in 2009 , when 'Rembrant $\mathrm{F}_{1}$ ' was characterized by a greater dry matter content than
'Spiros $\mathrm{F}_{1}$ '. Generally, Aminoplant in a dose of $3.0 \mathrm{dm}^{3} \mathrm{ha}^{-1}$ lowered dry matter content in spinach leaves as compared to the control. The interaction between the treatments showed that spraying with Aminoplant lowered dry matter content in spinach leaves in 'Spiros $\mathrm{F}_{1}$ ' cultivated in the autumn in the first year of the experiment and in 'Rembrandt $F_{1}$ ' cultivated in the spring in the second year of the experiment, as compared to the control.

Nitrate content that is too high may be a problem especially for vegetables with a short vegetation period, grown in highly fertilized soil, in soil rich in organic matter, or under poor lighting conditions. Several studies demonstrated that the application of biostimulants was able to reduce the nitrate content of leafy vegetables (Vernieri et al. 2005). Amanda et al. (2009) evaluated the use of biostimulant for reducing nitrate content and improving the commercial quality of baby leaf lettuce. In conclusion, the biostimulant was able to increase the yield, but only a slight effect on nitrate metabolism was observed. The Activawe biostimulant lowered leaf nitrate contents by $11-33 \%$ in rocket in a floating system (Vernieri et al. 2005). According to Mladenova et al. (1998), Aminoplant positively influenced nitrate reductase activity. In the present experiment, the influence of Aminoplant on nitrate content in spinach was differentiated between treatments (Tab. 4). The lowest nitrate content was found in 'Rembrandt $\mathrm{F}_{1}$ ' in the spring cultivation, treated with Aminoplant in a dose of $3.0 \mathrm{dm}^{3} \mathrm{ha}^{-1}$ in 2008 or $1.5 \mathrm{dm}^{3} \mathrm{ha}^{-1}$ in 2009. In autumn 2008, both cultivars sprayed with Aminoplant in a dose of 1.5 $\mathrm{dm}^{3} \mathrm{ha}^{-1}$ were characterized by the highest nitrate 


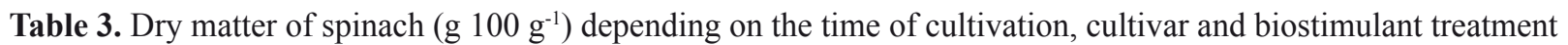

\begin{tabular}{|c|c|c|c|c|c|}
\hline \multirow{2}{*}{ Treatment } & \multicolumn{2}{|l|}{ Spring } & \multicolumn{2}{|l|}{ Autumn } & \multirow{2}{*}{ Mean for treatmen } \\
\hline & 'Rembrandt $\mathrm{F}_{1}$ ' & 'Spiros $F_{1}$ ' & 'Rembrandt $\mathrm{F}_{1}$ ' & 'Spiros $\mathrm{F}_{1}{ }^{\prime}$ & \\
\hline \multicolumn{6}{|c|}{2008} \\
\hline Control & $6.7 a^{*}$ & $6.9 \mathrm{a}$ & $10.6 \mathrm{~cd}$ & $11.2 \mathrm{~d}$ & $8.85 \mathrm{~B}$ \\
\hline Aminoplant $1.5 \mathrm{dm}^{3} \mathrm{ha}^{-1}$ & $6.6 \mathrm{a}$ & $6.6 \mathrm{a}$ & $11.0 \mathrm{~d}$ & $9.2 \mathrm{bc}$ & $8.35 \mathrm{AB}$ \\
\hline Aminoplant $3.0 \mathrm{dm}^{3} \mathrm{ha}^{-1}$ & $6.6 \mathrm{a}$ & $6.3 \mathrm{a}$ & $10.2 \mathrm{~b}-\mathrm{d}$ & $8.8 \mathrm{~b}$ & $7.98 \mathrm{~A}$ \\
\hline Mean for cultivar & $6.64 \mathrm{~A}^{* *}$ & $6.60 \mathrm{~A}$ & $10.60 \mathrm{~B}$ & $9.74 \mathrm{~B}$ & \\
\hline Mean for time of cultivation & $6.62 \mathrm{~A}$ & & $10.17 \mathrm{~B}$ & & \\
\hline \multicolumn{6}{|c|}{2009} \\
\hline Control & $9.1 \mathrm{~d}$ & $7.4 \mathrm{~b}$ & $9.4 \mathrm{~d}$ & $9.1 \mathrm{~d}$ & $8.75 \mathrm{~B}$ \\
\hline Aminoplant $1.5 \mathrm{dm}^{3} \mathrm{ha}^{-1}$ & $8.5 \mathrm{c}$ & $8.4 \mathrm{c}$ & $9.4 \mathrm{~d}$ & $9.1 \mathrm{~d}$ & $8.85 \mathrm{~B}$ \\
\hline Aminoplant $3.0 \mathrm{dm}^{3} \mathrm{ha}^{-1}$ & $7.2 \mathrm{ab}$ & $6.7 \mathrm{a}$ & $9.3 \mathrm{~d}$ & $9.0 \mathrm{~d}$ & $8.05 \mathrm{~A}$ \\
\hline Mean for cultivar & $8.27 \mathrm{~B}$ & $7.50 \mathrm{~A}$ & $9.37 \mathrm{D}$ & $9.07 \mathrm{C}$ & \\
\hline Mean for time of cultivation & $7.89 \mathrm{~A}$ & & $9.22 \mathrm{~B}$ & & \\
\hline
\end{tabular}

*,**Explanations: see Table 1

Table 4. Nitrate content in spinach ( $\mathrm{mg} \mathrm{NO}_{3} \mathrm{~kg}^{-1} \mathrm{f} . \mathrm{m}$.) depending on the time of cultivation, cultivar and biostimulant treatment

\begin{tabular}{|c|c|c|c|c|c|}
\hline \multirow{2}{*}{ Treatment } & \multicolumn{2}{|l|}{ Spring } & \multicolumn{2}{|l|}{ Autumn } & \multirow{2}{*}{ Mean for treatment } \\
\hline & 'Rembrandt $\mathrm{F}_{1}{ }^{\prime}$ & 'Spiros $F_{1}$ ' & 'Rembrandt $\mathrm{F}_{1}{ }^{\prime}$ & 'Spiros $F_{1}$ ' & \\
\hline \multicolumn{6}{|c|}{2008} \\
\hline Control & $2230 \mathrm{bc}^{*}$ & $2006 \mathrm{~b}$ & $2004 \mathrm{~b}$ & $2302 \mathrm{bc}$ & $2135.5 \mathrm{~A}$ \\
\hline Aminoplant $1.5 \mathrm{dm}^{3} \mathrm{ha}^{-1}$ & $2064 \mathrm{bc}$ & $2022 \mathrm{~b}$ & $3506 \mathrm{~d}$ & $3326 \mathrm{~d}$ & $2729.5 \mathrm{~B}$ \\
\hline Aminoplant $3.0 \mathrm{dm}^{3} \mathrm{ha}^{-1}$ & $1469 \mathrm{a}$ & $2172 \mathrm{bc}$ & $2370 \mathrm{c}$ & $2116 \mathrm{bc}$ & $2031.8 \mathrm{~A}$ \\
\hline Mean for cultivar & $1921.0 \mathrm{~A}^{* *}$ & $2066.7 \mathrm{~B}$ & $2626.7 \mathrm{C}$ & $2581.3 \mathrm{C}$ & \\
\hline Mean for time of cultivation & $1993.9 \mathrm{~A}$ & & $2604.0 \mathrm{~B}$ & & \\
\hline \multicolumn{6}{|c|}{2009} \\
\hline Control & $1016 \mathrm{ab}$ & $1706 \mathrm{~b}-\mathrm{d}$ & $2741 \mathrm{~d}$ & 1991 b-d & $1863.5 \mathrm{~A}$ \\
\hline Aminoplant $1.5 \mathrm{dm}^{3} \mathrm{ha}^{-1}$ & $558 \mathrm{a}$ & $1579 a-c$ & $2242 \mathrm{~cd}$ & $1820 \mathrm{~b}-\mathrm{d}$ & $1549.8 \mathrm{~A}$ \\
\hline Aminoplant $3.0 \mathrm{dm}^{3} \mathrm{ha}^{-1}$ & $1776 \mathrm{~b}-\mathrm{d}$ & $1438 \mathrm{a}-\mathrm{c}$ & 1988 b-d & 2018 b-d & $1805.0 \mathrm{~A}$ \\
\hline Mean for cultivar & $1116.7 \mathrm{~A}$ & $1574.3 \mathrm{AB}$ & $2323.7 \mathrm{C}$ & 1943.0 BC & \\
\hline Mean for time of cultivation & $1345.5 \mathrm{~A}$ & & $2133.4 \mathrm{~B}$ & & \\
\hline
\end{tabular}

***Explanations: see Table 1

content. However, in autumn 2009, the highest nitrate content was found in 'Rembrandt $\mathrm{F}_{1}$ ' control plants. The obtained results confirmed the frequent differentiation in nitrate content in field cultivated vegetables (Wojciechowska 2004).

\section{CONCLUSIONS}

1. Spinach yield was dependent on the time of cultivation and cultivar type. 'Spiros $F_{1}$ ' and 'Rembrandt $\mathrm{F}_{1}$ ' yielded better in the autumn cultivation. Spraying with Aminoplant had no effect on spinach yield.

2. Spinach grown in autumn had greater dry matter content in comparison to the spring cultivation.
In most of treatments, differences between cultivars and doses of Aminoplant in dry matter content were not significant.

3. The influence of the time of production, cultivar and dose of Aminoplant on nitrate content in spinach was differentiated between treatments.

\section{REFERENCES}

AmandaA.,FerranteA.,Valagussa M.,PiaggesiA.,2009. Effect of biostimulants on quality of baby leaf lettuce grown under plastic tunnel. Acta Hort. 807: 407-412 http://www.actahort.org/books/807/807_58.htm

CaO G., Sofic E., Prior R., 1996. Antioxidant capacity of tea and common vegetables. J. Agric. Food Chem. 44: 3426-3431. 
Cho M.J., Howard L.R., Prior R.L., Morelock T., 2008. Flavonoid content and antioxidant capacity of spinach genotypes determined by high-performance liquid chromatography/mass spectrometry. J. Sci. Food Agricul. 88(6): 1099-1106.

Dobromilska R., Gubarewicz K., Konieczny M., 2009. Wpływ preparatów $\mathrm{z}$ glonów morskich na plon i jakość pomidora uprawianego pod osłonami. Zesz. Probl. Post. Nauk Roln. 359: 143-149.

Grabowska A., Kunicki E., 2009. Wpływ wybranych biopreparatów na plonowanie brokułu w uprawie wiosennej. Zesz. Probl. Post. Nauk Roln. 359: 193-197.

KowalczyK K., Zielony T., 2008. Wpływ preparatów Aminoplant i Asahi na plonowanie i jakość sałaty w uprawie na wełnie mineralnej. Mat. Konf. „Biostymulatory w nowoczesnej uprawie roślin”, 7-8 luty, Warszawa: 40.

Łyszkowska M., Gajc-Wolska J., Kubić K., 2008. Wpływ biostymulatorów na plonowanie i jakość sałaty listkowej i kruchej. Mat. Konf. „Biostymulatory w nowoczesnej uprawie roślin", 7-8 luty, Warszawa: 158.

MAINI P., 2006. The experience of the first biostimulant based on amino acids and peptides: a short retrospective review on Fertilitas Agrorum 1(1): 29-43.

Mladenova Y.I., Maini P., Mallegni C., Goltsev V., Vladova R., Vinarova K., Rotcheva S., 1998. Siapton. An amino-acid-based biostimulant reducing osmostress metabolic changes in maize. Agro Food Ind. Hi-Tech. 9: 18-22.

StĘPOWSKA A., 2008. Biostymulatory stosowane w uprawie papryki słodkiej pod osłonami. Mat. Konf. „Biostymulatory w nowoczesnej uprawie roślin”, 7-8 luty, Warszawa: 36.

Vernieri P., Borghesi E., Ferrante A., Magnani G., 2005. Application of biostimulants in floating system for improving rocket quality. J. Food, Agric. Environ. 3(3-4): 86-88.

Vernieri P., Malorgio F., Tognoni F., 2002. Use of biostimulants in production of vegetable seedlings. Colture-Protette 31(1): 75-79.

Wojciechowska R., 2004. Some aspects of nitrate metabolism in vegetables with special references to buttterhead lettuce 'Sprinter'. Zesz. Nauk AR w Krakowie, ser. Rozprawy 297.

Yildirim E., Dursun A., Güvenc I., Kumlay A.M., 2002. The effects of different salt, biostimulant and temperature levels on seed germination of some vegetable species. Acta Hort. 579: 249-253, http:// www.actahort.org/books/579/579_41.htm

\section{WPEYW ODMIANY, TERMINU UPRAWY I ZASTOSOWANIA BIOSTYMULATORA NA PLONOWANIE SZPINAKU (SPINACIA OLERACEA L.)}

Streszczenie: Celem badań było określenie wpływu dawki biostymulatora Aminoplantu na plonowanie dwóch odmian szpinaku $\mathrm{w}$ uprawie wiosennej i jesiennej, w latach 2008 i 2009. Czynnikami doświadczenia były: (1) odmiana: 'Rembrandt $\mathrm{F}_{1}$ ' i 'Spiros $\mathrm{F}_{1}$ ', (2) termin uprawy: wiosna i jesień, (3) dawka Aminoplantu: kontrola (bez Aminoplantu), 1,5 $\mathrm{dm}^{3} \mathrm{ha}^{-1}$ i 3,0 $\mathrm{dm}^{3} \mathrm{ha}^{-1}$. Plon szpinaku zależał od terminu uprawy oraz odmiany i mieścił się w zakresie 18,6-44,8 $\mathrm{t} \mathrm{ha}^{-1}$. Obydwie odmiany plonowały lepiej $\mathrm{w}$ terminie jesiennym. Zastosowanie Aminoplantu nie wpłynęło na wielkość plonu szpinaku. Zawartość suchej masy w liściach szpinaku mieściła się w zakresie 6,3-11,2 g $100 \mathrm{~g}^{-1}$. Rośliny uprawiane w terminie jesiennym zawierały więcej suchej masy $\mathrm{w}$ porównaniu $\mathrm{z}$ terminem wiosennym. W 2009 roku odmianę 'Rembrant $\mathrm{F}_{1}$ ' charakteryzowała większa zawartość suchej masy w porównaniu do odmiany 'Spiros $\mathrm{F}_{1}$ '. Aminoplant w dawce $3,0 \mathrm{dm}^{3} \mathrm{ha}^{-1}$ obniżył zawartość suchej masy $\mathrm{w}$ liściach szpinaku $\mathrm{w}$ porównaniu do kontroli. Wpływ badanych czynników na zawartość azotanów (558-3506 mg NO $\mathrm{kg}^{-1}$ św.m.) był niejednoznaczny i zróżnicowany pomiędzy obiektami doświadczenia.

Received April 27, 2010; accepted November 29, 2010 